\title{
USE OF ANALYTIC HIERARCHY PROCESS (AHP) TO IDENTIFY DECISION FACTORS IN THE DEPLOYMENT OF PUBLIC AND PRIVATE PORT TERMINALS IN THE NORTHERN BRAZIL
}

\begin{abstract}
Brazilian agribusiness plays an important role in world trade, especially soy. The CentralWest and North regions have shown expansion of production and, thus, requiring new export alternatives. Decision factors for the investment of specialized port terminals in the area known as Arco Norte, that is, ports located in the Northeast and North of the country are addressed in this paper. The Analytic Hierarchy Process (AHP) decision tool was used as a methodology using a questionnaire applied to managers and specialists of the port scenario, to identify and qualify decision criteria for investments in the alternatives of public port terminal leasing and private terminal deployment, possibilities considered in Brazilian regulatory legislation. Priority was for the investment on Private Use Terminals, which has been effective in recent years.
\end{abstract}

Keywords: Multi-criteria analysis, Arco Norte Logistics Platform, Soybean Export.

\section{Introduction}

Agribusiness has played a strategic role in increasing the country's participation in the international market. However, the outflow of agricultural products to export ports is still limited by operational restrictions imposed by the transport and port infrastructure. Although the increase in global demand for soybeans has boosted its cultivation in Brazil, the main agricultural commodity exported, logistical costs are still an obstacle to greater competitiveness of Brazilian production. Arco Norte Logistics Export Corridor, also known as the Arco Norte System, presents itself as an alternative for production export originated in Mato Grosso, the main state producer of soybeans. This system consists of multimodal corridors and operational support platforms located in Porto Velho, Rondônia and Miritituba, in the state Pará. These platforms allow transport of grain production to the export ports located in Itacoatiara, in the state of Amazonas; Santarém, Barcarena and Vila do Conde, in Pará; São Luís, in Maranhão; and Santana, in Amapá.

To solve obstacles in the port sector, the Federal Government modified the regulatory framework of the Brazilian port sector through the New Port Law $N^{\circ} 12.815 / 2013$ and decrees, with the explicit objective of unlocking investments in the sector, giving agility to public investments in ports, and to promote efficiency in port operations, as well as to encourage new investments in terminals for private use. The research shows the importance of consolidating information that allows to optimize investments in face of the current and future needs of the national logistics and port systems. The research applies the Analytic Hierarchy Process (AHP) method to identify decision factors in the port terminal deployment in the Northern Region of Brazil, considering the possibility of leasing the public port and private use terminal.

\section{Literature Review}

The AHP (Analytic Hierarchy Process) multicriteria analysis method is based on an active weighting process, in which the various relevant attributes are represented by their relative 
importance. This method is characterized by the division of the problem into descending hierarchical levels, starting with the global objective, criteria, sub criteria and alternatives at successive levels (Saaty, 2001).

Gartner, Rocha, \& Granemann (2012) applied the AHP method to problems of regulation, planning and management of ports in privatized port areas, due to their multidisciplinary nature, involving socio-economic, environmental and political value judgments. According to Loureiro, Freitas, \& Gonzales (2015), the location decision can be analysed through criteria related to road access, availability of area for expansion, socioenvironmental impacts, and local infrastructure conditions using AHP.

Mazza \& Robles (2004) analysed the use of the AHP methodology, applied as a tool to support their decision process on port options with containers for export. The analysis was based on financial and operational criteria, which involve port tariffs, level of service, operational capacity and financial stability, identifying the location of a port as the first factor of great representativeness in the costs incurred by the shippers. Then the conditions of access to the port are obtained, according to the characteristics of terrestrial access and navigability.

Miranda (2008) used the method to support the decision of logistic operators in the choice of the transportation corridor and its port specialized in the shipment of agricultural bulk produced in Sinop, Campo Novo do Parecis and Rondonópolis in Mato Grosso. The application of the AHP method for decision making processes in the public port sector is common, although its use is reduced for port lease project analysis. In the same way, the methodology can be indicated as the main decision tool in regulatory problems in privatized port areas (Magalhães \& Botter, 2015).

\section{Hypotheses/Objectives}

The Decree 9.048 / 2017 and its amendments that regulate the Law of Ports No. 12.815 / 2013 demonstrate the Federal Government's effort to stimulate more investments in the Brazilian port sector. The lack of interested parties in the leasing of port area and infrastructure within the organized port, the first publication of the bidding documents in 2013, and the prioritization of private terminals in the Arco Norte Logistic Corridor shows investors' insecurity in leasing public port facilities.

Thus, this paper was based on the Analytic Hierarchy Process (AHP) method to identify and evaluate the main criteria analysed by decision-makers in the choice of investments, since the alternatives of leasing of area and infrastructure in organized port and implementation of private use terminal. The research consolidated information that allows to optimize investments in relation to the current and future needs of the national logistics system and to identify the decision-making factors for investments between public and private use terminals.

\section{Research Design/Methodology}

This research uses AHP method as a decision support tool to evaluate and select the most viable type of port facility for soybean export operations in the northern region of Brazil. The objective was to identify the main relevant criteria to assist the decision maker in the choice of investment, considering the possibilities of public port leasing or private use terminal implementation. The AHP structure was elaborated based on 4 criteria and its subsequent sub 
criteria obtained from literature review and expert experience. Each criteria are evaluated by the respective sub criteria, compared with each other, in importance scale ranging from 1 to 9 of relative intensity (Saaty, 2001).

Figure 1 - Hierarchy Structure Applied to Search

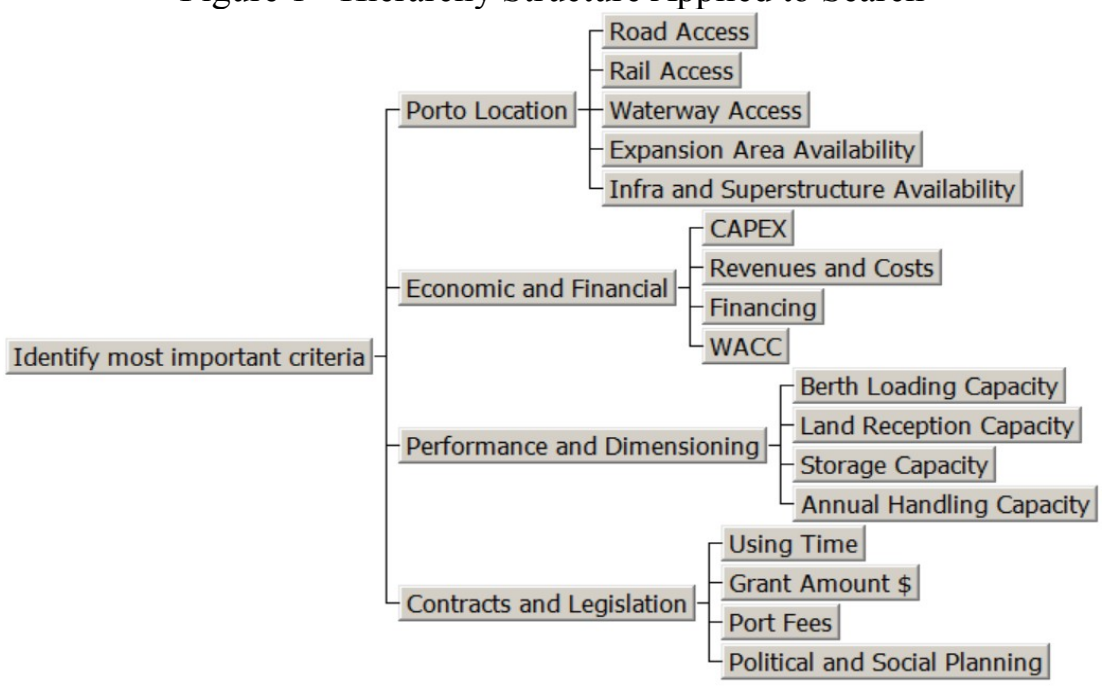

Source: Excerpted from Expert Choice software

The criteria " Port Location" is related to the availability of infrastructure and superstructure of transport and port in the region, considering land and waterway access, availability of areas for future expansion and port structures. The "Economic and Financial" criteria considers the determining factors for the technical, economic / financial, and environmental feasibility analysis of the terminal.

The "Performance and Dimensioning" involves the operational efficiency of the terminal. It is directly related to the operational capacity installed in the terminal. It considers the boarding capabilities, land reception, warehousing and annual handling. The criteria "Contracts and Legislation" was proposed for evaluating the requirements and constraints of public notices for lease of terminal in public port, as well as the legislation that regulates the authorization of terminals for private use, and national development plans.

After the hierarchy's construction, the phase of defining priorities and comparative judgments was carried out, where each decision maker had to make a comparison of criteria at a given hierarchical level submitted through a questionnaire applied on-line from app Google Forms. Firstly, contact was made by e-mail, telephone and social network (LinkedIn) to check the availability of the decision-making group to participate in the survey. The decision-making group is comprised of 19 (nineteen) specialists that involve engineering consulting and port operations, five (5) academic researchers, and 11 (eleven) professionals in the surveillance and regulation of waterway transport services and ports.

\section{Data/Model Analysis}

Once the values of the decision-makers' priority judgments were obtained, is was used Expert Choice software in its "Demo" version. The Expert Choice structured decision tool allowed to calculate the local average priorities and the overall priorities, ensuring the normalization of the matrices and the logical consistency of the judgments. Subsequently, twelve (12) decision 
makers' judgments were added only, normalizing the data and verifying the consistency of the judgments, which allowed to obtain the results of the local average priorities and global priorities, as presented beneath.

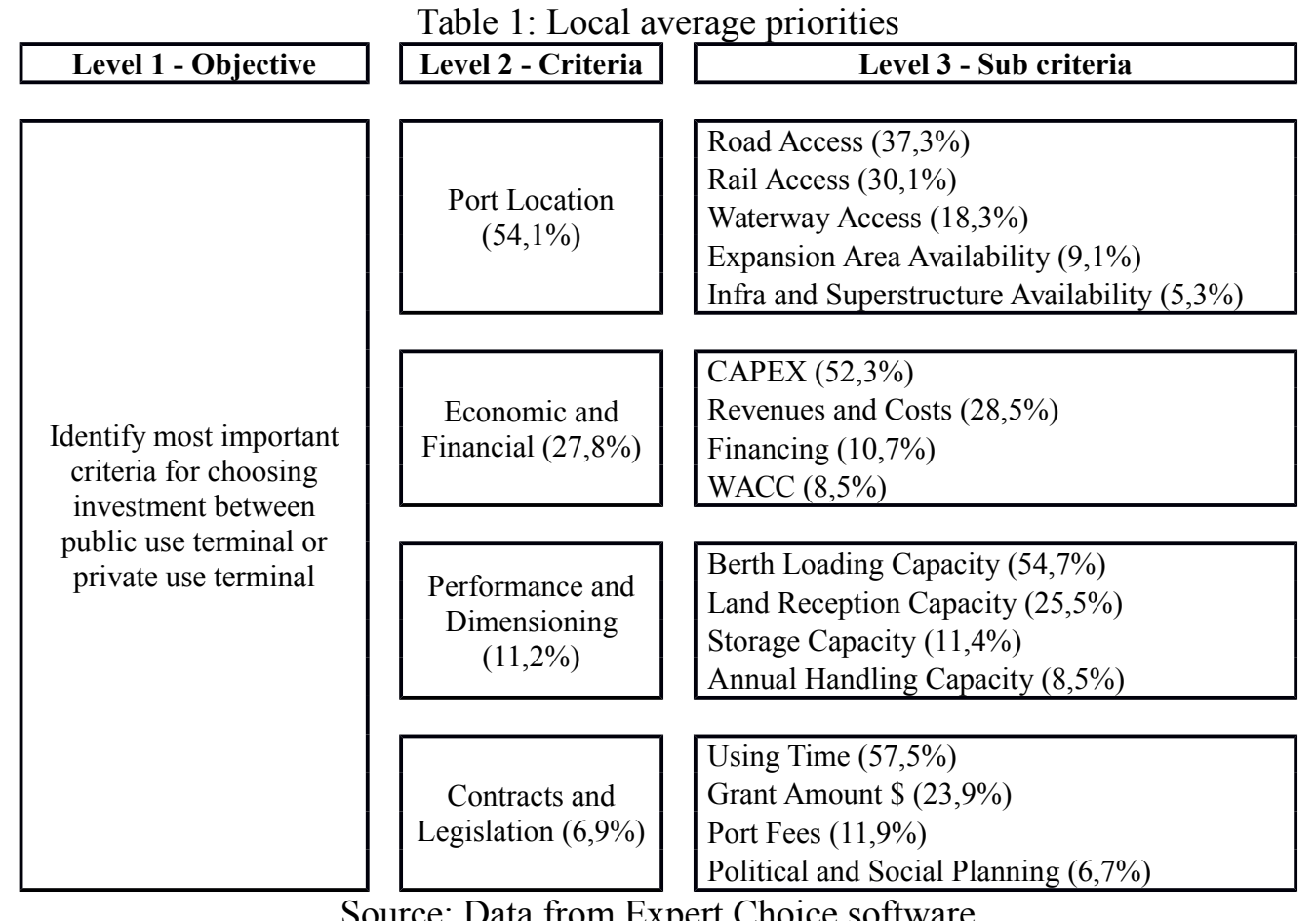

Source: Data from Expert Choice software

In the Port Location criteria, the importance of sub-criteria, Road Access and Rail Access, stood out with $37.3 \%(0.373)$ and $30.1 \%(0.301)$, respectively. The analysis results of the Economic and Financial criteria show the predominance of the sub criteria CAPEX 52.3\% (0.523) followed by sub criteria Revenues and Costs $28.5 \%(0.285)$. Performance and Dimensioning criteria has as results the importance of Berth Loading Capacity $54.7 \%(0.547)$ higher than the other sub criteria. The analysis of the Contract and Legislation criteria shows the sub criteria Using Time 57.5\% (0.575) as the most relevant. Global Priorities can be achieved through the product of all intermediate priorities from the lowest hierarchical level to the highest. Graph 1 shows that the criteria of greater adherence to the overall objective was Port Location 54.1\% (0.541). The following are the Economic and Financial criteria: $27.8 \%$ (0.278), Performance and Dimensioning 11.2\% (0.112) and Contract and Legislation $6.9 \%(0.069)$.

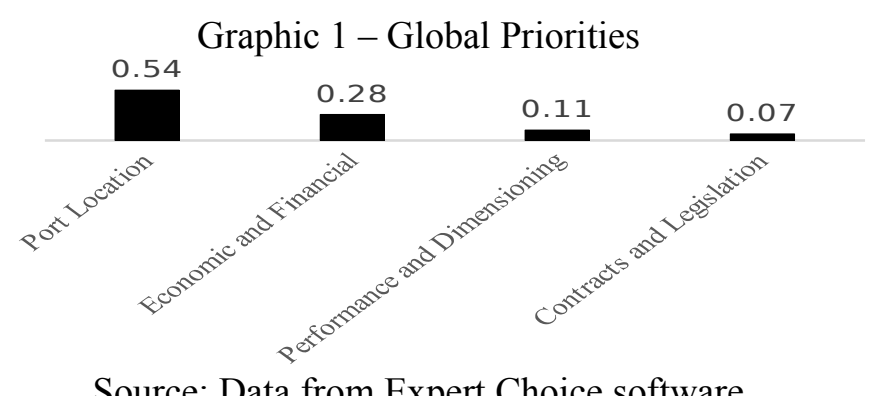


The priorities of sub criteria in relation to the overall objective are the sub criteria Road Access 23.4\%, Rail Access 18.9\%, CAPEX 12.1\% and Waterway Access 11.5\%, which together total $65 \%$ importance for decision making between investment in public terminals and private. In the end, decision-makers were asked to invest in a port facility model for grain exports on the routes of the north and northeast of Brazil, which they would choose. All interviewees opted for the implementation of private use terminals.

\section{Limitations}

The AHP method can promote the entire Brazilian port sector, through the knowledge and comparative analysis of investment alternatives, thus contributing to agribusiness efforts. However, it was difficult to get answers from the 35 specialists. Although solicitous, only 12 (twelve) decision-makers answered the questionnaire. It is needful that they are engaged and committed, because the lack of data and inconsistent judgments can intervein in results analysed.

\section{Conclusions}

The results showed the Port Localization of $54 \%$ criteria as most important. The values of the global judgments of the sub criteria points to the prioritization of the criteria of Port Location, road access and rail access. The low density of the railway network and the low utilization of the waterways, used in the export routes, justify the predominant use of the modal road. The Economic and Financial criteria presented priority to the sub criteria CAPEX and Revenues and Costs. CAPEX, capital needed to invest in the construction and implementation of the terminal, is an essential factor for the feasibility analysis of the terminal, verified mainly in the project phase. The research found that $100 \%$ of the experts interviewed would still have their preference for investment in private use terminals. The result goes in accordance the real situation in Brazil.

The use of the AHP multicriteria analysis methodology was able to meet the objective of the study, which, in addition to identifying the main criteria for choosing an investment model, offers decision makers and interested parties' conditions for analysis and choice of alternatives between terminal public and private terminal. Is recommended for future studies the application of the method in situations that involve multiple alternatives of public and private terminals of different characteristics. The use of the tool can still be extended to specialized terminals in the movement of the different types of load. It is suggested that the method be applied with a larger number of professionals, including also interested investors.

\section{Key References}

Gartner, I. R., Rocha, C. H., \& Granemann, S. R. (2012). Modelagem Multicriterial Aplicada a Problemas de Regulação em Áreas Portuárias Privatizadas. Rio de Janeiro.

Magalhães, J. R., \& Botter, R. C. (2015). Modelo de Análise Multicritério de Apoio à Decisão para Aprovação de Novos Terminais Portuários Privativos no Brasil. I Congresso Internacional de Desempenho Portuário. 
Mazza, M., \& Robles, L. T. (2004). Análise dos fatores de decisão na escolha de portos brasileiros na logística de exportação de carga conteinerizada na perspectiva do embarcador: uma proposta metodológica. XI SIMPEP.

Miranda, L. M. (2008). Contribuição a um Modelo de Análise Multicritério para Apoio à Decisão da Escolha do Corredor de Transporte para Escoamento da Produção de Granéis Agrícolas de Mato Grosso. COPPE/UFRJ.

Loureiro, J. F., Freitas, R. R., \& Gonzales, W. (2015). Proposta de um método de localização para expansão de um terminal portuário por meio do Analytic Hierarchy Process (AHP). 